\title{
Campus Security and Safety Models: Statistical Empirical Analysis from a Ghanaian Tertiary Institution
}

\author{
Francis Owusu Mensah (Ph.D) Joseph Antwi Baafi (Ph.D) Yarhands Dissou Arthur \\ Claudia Omari Somuah Richard Mprah \\ 1.Associate Professor, Director - Institute of Distance and Learning e-Learning, University of Education, \\ Winneba \\ 2.Lecturer, Department of Accounting Education, University of Education Winneba \\ 3.Senior Lecturer, Department of Interdisciplinary Education, University of Education, Winneba \\ 4.Principal Administrative Assistant, Department of Hospitality and Tourism Education, University of \\ Education, Winneba \\ 5.Senior Assistant Registrar, Head of Human Resources, University of Education, Winneba - Kumasi Campus
}

\begin{abstract}
All over the world security challenges faced by our traditional settlements is likewise in the university and college campuses. For this reason campus safety and security has become topical issue of research since parents are concerned about their wards and educational stakeholders risk losing loosing students because of crime and violence. With the influx of distance education students on the campus during the weekends and holidays, the issue of security becomes even more paramount. The current study model students' perception of campus security personnel's using procedural fairness, security effectiveness and trust in security response construct while fear of crime as well as security corruption are used as predictor construct. PLS-SEM is the quantitative approach used to investigate effect security corruption and students fear of crime on security procedural fairness, security effectiveness and students' trust in security. The study randomly selected 350 regular and distance students, however 327 returned questionnaires resulting to $93 \%$ response rate. The study revealed that students' fear of crime and security corruption predicts $71.8 \%$ of students' trust in security. Furthermore, security corruption and students fear of crime account for $31.2 \%$ of students' perceived security personnel's procedural fairness. Finally, the study found that security corruption and students fear of crime accounts for $39.5 \%$ of the variability in security personnel's effectiveness. The study concluded that students' fear of crime positively affect their trust in campus security, however, the corruption on the part of campus security negatively affect students' trust in campus security, security personnel's procedural fairness and effectiveness. The authors recommend that training programmes should be put in place regularly to sensitise personnel's on the effect of corruption on their integrity and profession. Keywords: Fear of crime, Security effectiveness, Security corruption, procedural fairness
\end{abstract}

DOI: $10.7176 / \mathrm{JEP} / 10-12-07$

Publication date: April $30^{\text {th }} 2019$

\section{Introduction}

The universities and colleges not until recent times operates with the doctrine of in loco parentis where institutions of higher learning exercise parental control over students enrolled at universities and colleges (Conrath, 1976). Today, the doctrine of in loco parantis has disappeared from college and university life where students are considered adults and are free to consume and engage in various activities that gratify their emotional, spiritual and social needs. In our modern day university or college, it is arguably true that the deviation from the doctrine of in loco parentis has led to two view point regarding relationship between students and the modern-day College or university (Pendlay, 2006).

The first viewpoint contends the university and the student have enviable relationship and further acknowledges that students have exclusive right of independence over their own affairs as an adult (Patel, 2019). Additionally, the second view point establishes that the unique relationship between university students and the university place duty of care on the university to protect students from harm (Patel, 2019). The significance placed by both parents and students on the choice of university or colleges is increasing worldwide due to free range nature of our colleges and university. Just as most communities today even those found in the most pastoral settings, colleges and university campus are no longer safe havens. In the most western world, nearly a million college students may carry weapons as safety measure a situation that has accounted for campus safety being on the minds of both parents and students as very important factor to be considered selecting a tertiary institution (Institute of Legislative Action, 2016). The importance parents and students attached to campus security may be as a result of students' risk of crime being influenced to commit crime in college or university. A study has shown that crime at college students' risk of crime at college is greater than the risk at homes (The Conversation, 2016).

Recognizing the importance of security by both parents and students in colleges and universities has compelled these institutions to establish security units or department which is operated by university security staff or private security. Most studies on campus security focuses on the crime perpetrated by students or perpetrated 
on students a paradigm this current study may not follow however focus on the activities of security personnel and students' perception on these personnel's.

In Ghana most public and private universities operates their own security services and are charged with the responsibilities of ensuring safety of both student and the university staff as well as protecting properties of the university. The discharge of their duties of protecting properties and ensuring safety of students and staff of the university may be assessed using security personnel's effectiveness, procedural fairness, security corruption, students' fear of crime and students trust in security (Auburn, 2011). The students perception about security effectiveness, procedural fairness, security corruption and student trust in security have been the concern of both parents and students in Ghana and require empirical investigation. Not only are we interested in security of regular students, interest has also been building in the area of security for distance students.

Perraton (1988) defines distance education 'as an educational process in which a significant proportion of the teaching is conducted by someone removed in space and/or time from the learner'. Keegan (1996) goes further to identify the key characteristics of distance education. According to him, distance education is a form of education characterised by: the quasi-permanent separation of teacher and learner throughout the length of the learning process; the influence of an educational organization both in the planning and preparation of learning materials and the provision of student support services; the use of technical media-print, audio, video or computer - to unite teacher and learner and carry the content of the course; the provision of two-way communication so that the student may benefit from or even initiate dialogue and the quasi-permanent absence of the learning group throughout the length of the learning process so that people are usually taught as individuals rather than in groups, with the possibility of occasional meetings, either face-to-face or by electronic means, for both didactic and socialization purposes (Keegan, 1996).

According to Perraton, Ministries of Education have found distance education methods attractive because these methods, make it possible to reach students who cannot get to college, lend themselves to part-time education so that students are not taken out of the work force in order to study and appear to allow economies of scale, in part by avoiding the need for new buildings including housing for students (Perraton, 1993). As a result of the above advantages most adult learners the world over use the distance learning mode to upgrade themselves. Weekly face-to-face sessions of the distance students take place at the campuses of our colleges and universities. There a good majority of the students found on the campuses of universities and colleges during the weekends and holidays are distance students. Therefore the issue of campus security largely affects both distance and regular students.

It is from this backdrop this study seeks to model students' trust in security, security procedural fairness and effectiveness of the security and to include distance students. The objectives of the study are group in three main parts. The first part seeks to determine the effect of students' fear of crime and perceived security corruption on personnel's procedural fairness. The second part seeks to examine the effect of students' fear of crime and perceived security corruption on students' trust in security personnel. The last part seeks to ascertain the effect of students' fear of crime and perceived security corruption on personnel's effectiveness. In trying to address these objectives, the study developed six different hypotheses. All these analysis would include distance students. Details of the hypotheses would be shown later.

\section{Literature Review}

The concept of security on various higher institutions' campus around the world has been a great concern to many researchers. Different researchers have discussed various aspects security on campus.

Sulkowski (2011) investigated students' willingness to report threat of violence on campus of higher institution. Using structural equation with a sample size of 967 from university in the South of US and finding measures of variables such as campus connectedness, self-efficacy towards service, delinquency and trust in the college support system the researcher brought forth an interesting findings and made a good recommendation. The results found that, trust on college support system, self-efficacy and feeling connected to campus environment was positively linked to students' willingness to report threat of violence. Even though the relationship between selfefficacy and willingness were only possible when trust was present. The study therefore recommend that to improve upon safety, students should be encouraged to report threat by ensuring that collages work toward increasing trust and connectedness in campuses of higher institution.

Seo (2012) worked on campus violence preparedness of US colleges' campuses. Using logistic regression on a sample size of 161 participants from various US college institutions and conducting an online survey, a researcher found that even though there a emergency procedures available on various campus, 25 percent of the participant agreed that those emergency procedures are understood by students. On time of notification, 25 percent seem to have the information that in case of serious violence activities, students would be notified in the next five minutes. Most participants according to the researcher do not realize the importance of emergency drills and do not engage in campus-wide practice of them on a regular basis.

Gomme and Micucci (1997), reviewed series of study conducted on US and Canada. Even though crime and 
violence was mostly found in US that for Canada did not have large records. Possible explanation could be that there seem to be a strong policing strategy which may include recruitment, training, socialization and promotions which tend to work against the increasing violence and crime on campus. Another explanation could be that the media may not too interested in reporting crime and thus the needed attention is well limited. The authors however alluded to the fact that the former explanation is the likely explanation based on limited but available literatures. Volkwein et al (1995), used both longitudinal and cross-sectional database and found that campus rate of both violence and property crime has been falling since 1985 . The study further reveals that students are safer on campus than on surrounding communities

Other studies have turned attention to the possible causes of violence, and its prevention. Bellotti and Pezza (1995), found three main variables which is suspected to be associated with campus violence. These are predisposing, enabling and reinforcing violence behaviour. The study also revealed the role of alcohol in fuelling violent conduct. To prevent violence, the study adopted the framework that describes the level of prevention by Roark (1987). The framework prescribes the three steps of prevention as primary, secondary and tertiary. Primary preventive steps include education and training. Specifically training in social skills, assertiveness, sexual decision making, anger and stress management, conflict resolution and self-defence. Layden (2009) supports this view on confronting campus violence. Secondary preventive steps include letting students know exactly what is happening, communicating clearly what is acceptable and unacceptable behaviour, and establishing equally clear penalties for those in violation of standards. Tertiary preventive steps involve how first line individuals involved in violence are treated. Another preventive step proposed by Mills et al (1983) targets the social ecology and involves a relatively larger number of constitutes including faculty, staff and administration. Solution of violence involves changing social norms and behaviours. These steps in preventive technique are embedded in Langford (2009) principles in preventing technique.

Further to the above on the causes of campus violence, Langford (2009), identified enumerated five main factors. These are individual factors such as students, faculty and staff attitudes, interpersonal or group factors such as norm with respect to appropriate behaviours, institutional factors such as policies regarding security and safety as well as general campus environment, community factors such as prevalence of violence and drug trade in and around campus environment, and public policy and societal influences.

The research on campus safety appears to have been concentrated in developed countries. Few works on campus security exist in developing countries. Notable among them is Amoatemaa et al (2017). Working on students' perception of campus safety in Ghana, using 224 respondents, the authors found that 87.5 percent of respondents were concerned with security in campus. Students felt safer during the day than night hours. This result is consistent with Burruss et al (2010). Other places on campus such as isolated places, relatively poorly lit and dark areas posed threat to security on campus. This is also consistent with the study conducted by Burruss et al (2010). The study therefore recommends that close circuit television (CCTV), emergency phone service to call security personnel and security patrols could be used to improve upon safety on campus. This part of the study is however in contrast to Burruss et al (2010) and though Layden (2009) seem to agree with it.. The commonly reported crime issues are theft/attempted theft, burglary/attempted burglary, robbery/attempted robbery and physical attack (Burruss et al (2010).

Literature reviewed above and other existing studies have shown that even though various aspects of campus security and safety have been studied by researchers, the scope of study does not cover other areas. Again, studies have been conducted mostly in developed countries specifically US and Canada with little study conducted on Universities developing countries. One area where previous study appears to have failed to work on is the perception students have on campus security personnel. Halifax (2015) worked on a similar research topic but the study concentrated on the professional identifies of campus security staff. In other words security personnel were interviewed on their profession. The immediate issue about the study is an inherent bias that could be deduced from the evaluation of the personnel used in the study.

This study however drifts from other previous study in three main ways. Firstly, the main actors in terms of security on campus around the world been the personnel are the point of focus. Secondly, the security personnel are not directly involved in the study thus preventing issues of inherent bias. Thirdly, the study is conducted in university in developing country specifically Ghana thus contributing to knowledge in the area of campus security in developing country.

The conceptual model needed to address the objective of the study is displayed below 


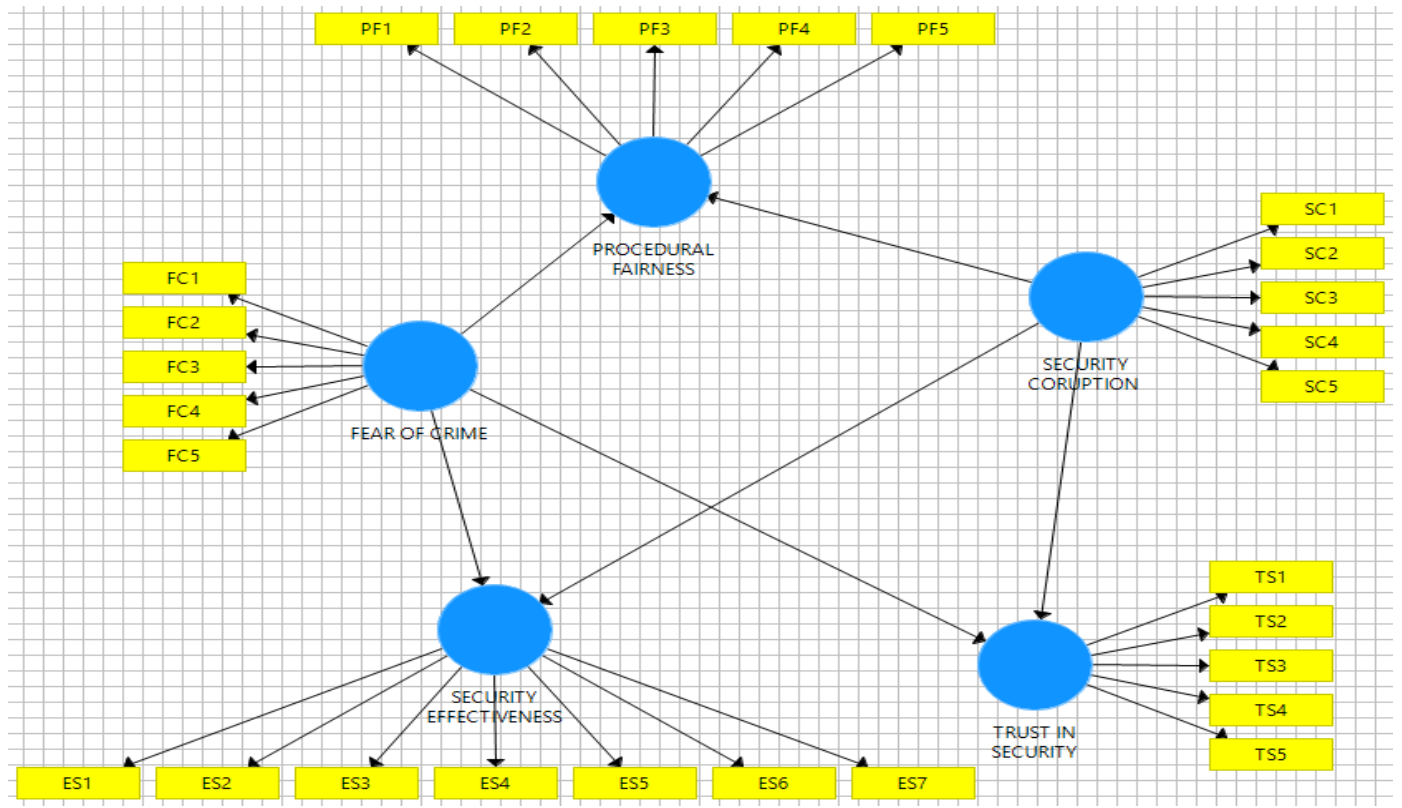

Figure 1: Conceptual Model Campus Security

The conceptual model displayed in figure 1 illustrates how the important variables used in the study are interconnected and interrelated. The main variables found in the model are fear of crime, procedural fairness, security corruption, trust in security and security effectiveness. All of these major variables are measured by other variables. Thus part of the model labelled FC1 to FC5, SC1 to SC5, TS1 to TS5, ES1 to ES7, and PF1 to PF5 all indicates sub-factors that are used as measures of the major variables used in the study. According to Auburn (2011), the main factors that measures fear of crime include the inclination to walk with a friend during dark hours, avoiding poorly lit roads, locking residential hall room door and windows are night and notifying security of suspicious individuals. Measures of trust in security are reporting crime, avoiding mob and instance justice, giving necessary information and tip-off about impending crime, asking for security escort and having the police as a friend. De Cremer et al (2010), measured procedural fairness using these five constructs; consistency, bias suppression, accuracy, correctability and ethnicity of the security. Kankanhalli et al (2003), developed constructs for measuring security effectiveness. These are as follows; preventive efforts, deterrent efforts, deterrent severity, industry type, organizational size and top management support. These measures were adopted in the current study. The model predicts possible interconnection and interrelationship that exist between the various variables. The model explains that fear of crime affects procedural fairness and security effectiveness and trust in security. Again model further predicts that security corruption affects procedural fairness, trust in security and security effectiveness.

\section{Methodology}

Because of the structural of the model presented in figure 1, the study made use of structural equation model to test the hypothesis already stated. Structural-equation models (SEMs) are multiple-equation regression models in which the response variable in one regression equation can appear as an explanatory variable in another equation (Fox, 2006). Structural equation models can include variables that are not measured directly, but rather indirectly through their effects (called indicators) or, sometimes, through their observable causes.

Assume variable $y$ and $x$. Variable $\mathrm{y}$ is understood to be a chosen observation. If we assume a similar situation for $x$, with SEM $y$ contains endogenous variables and $x$ contains exogenous variables. An endogenous variable simply means variable that appears at least once as the dependent variable, thus variable that appears on the righthand side are exogenous. Therefore all variance of and covariance between exogenous variables are determined outside of the system. The basic form of SEM appear as follows

$$
\begin{gathered}
{\left[\begin{array}{l}
Y_{1} \\
Y_{2} \\
\cdots \\
Y_{p}
\end{array}\right]=\left[\begin{array}{cccc}
0 & \beta_{12} & \cdots & \beta_{1 p} \\
\beta_{21} & 0 & \cdots & \beta_{2 p} \\
\cdots & \cdots & \cdots & \cdots \\
\beta_{p 1} & \beta_{p 2} & \cdots & 0
\end{array}\right]\left[\begin{array}{c}
Y_{1} \\
Y_{2} \\
\cdots \\
Y_{p}
\end{array}\right]+\left[\begin{array}{cccc}
\gamma_{11} & \gamma_{12} & \cdots & \gamma_{1 q} \\
\gamma_{21} & \gamma_{22} & \cdots & \gamma_{2 q} \\
\cdots & \cdots & \cdots & \cdots \\
\gamma_{p 1} & \gamma_{p 2} & \cdots & \gamma_{p q}
\end{array}\right]\left[\begin{array}{c}
X_{1} \\
X_{2} \\
\cdots \\
X_{p}
\end{array}\right]+\left[\begin{array}{c}
\zeta_{1} \\
\zeta_{2} \\
\cdots \\
\zeta_{p}
\end{array}\right]} \\
y=B y+\Gamma x+\zeta
\end{gathered}
$$

Where $\mathrm{p}$ by $\mathrm{p} \mathbf{B}$ matrix contains the coefficient of the regressions of $\mathrm{y}$ variable on other $\mathrm{y}$ variables with 0 's on the diagonal which implies that a variable cannot cause itself. The $p$ by q matrix $\boldsymbol{\Gamma}$ contains the coefficient of the $y$ 's on the $x$ 's. The error vector $\zeta$ is $\mathrm{p}$ by 1 . To estimate the model, the following assumption are made $\mathrm{E}(\mathrm{y})=0$ and $\mathrm{E}(\mathrm{x})=0, \operatorname{cov}(\mathrm{x}, \zeta)=0$ and the determinant $|I-B| \neq 0$. 
We now define $V(x)=E\left(x x^{\prime}\right)=\varphi$ and $V(x)=E\left(\zeta \zeta^{\prime}\right)=\psi$. From this we deduce the reduced form. This requires that we solve for the y vector as below

$$
\begin{gathered}
y=B y+\Gamma x+\zeta \\
y-B y=\Gamma x+\zeta \\
(1-B) y=\Gamma x+\zeta \\
y=(I-B)^{-1} \Gamma x+(I-B)^{-1} \zeta \\
y=G x+e
\end{gathered}
$$

What is the variance of the y variable?

$$
\begin{gathered}
\sum_{E\left(G x x^{\prime} G^{\prime}\right)+E\left(G x y^{\prime}\right)+E\left(e x^{\prime} G^{\prime}\right)+E\left(e e^{\prime}\right)}=E\left[(G x+e)(G x+e)^{\prime}\right]
\end{gathered}
$$

The $2^{\text {nd }}$ and $3^{\text {rd }}$ term vanish using the rule of transpose of an inverse is the inverse of a transpose. We have

$$
E\left(y y^{\prime}\right)=G E\left(x x^{\prime}\right) G^{\prime}+E\left(e e^{\prime}\right)
$$

Having previously defined $V(x)=E\left(x x^{\prime}\right)=\varphi$ and $V(x)=E\left(\zeta \zeta^{\prime}\right)=\psi$ we have

$$
\begin{gathered}
E\left(y y^{\prime}\right)=(I-B)^{-1} \Gamma \varphi \Gamma^{\prime}\left(1-B^{\prime}\right)^{-1}+(1-B)^{-1} \psi(1-B)^{-1} \\
=(1-B)^{-1}\left[\Gamma \varphi \Gamma^{\prime}+\psi\right](1-B)^{-1}
\end{gathered}
$$

The covariance between $x$ and $y$ is

$$
\begin{gathered}
E\left(x y^{\prime}\right)=E\left[x(G x+e)^{\prime}\right] \\
=E\left[x x^{\prime} G^{\prime}+x e^{\prime}\right] \\
=E\left(x x^{\prime}\right) G^{\prime}+E\left(x \zeta^{\prime}\right)\left(I-B^{\prime}\right)^{-1} \\
=\varphi G^{\prime}+0+\varphi \Gamma^{\prime}\left(1-B^{\prime}\right)^{-1}
\end{gathered}
$$

Putting all the pieces together we have

$$
\begin{gathered}
\sum=\left[\begin{array}{ll}
\sum y y & - \\
\sum x y & \sum x x
\end{array}\right] \\
=\left[\begin{array}{cc}
(1-B)^{-1}\left[\Gamma \varphi \Gamma^{\prime}+\psi\right]\left(1-B^{\prime}\right)^{-1} & - \\
\varphi \Gamma^{\prime}\left(1-B^{\prime}\right)^{-1} & \varphi
\end{array}\right]
\end{gathered}
$$

In using structural equation models researchers undertake what is known as path analysis. A path analysis is an extension of the regression model used to test the fit of the correlation matrix against two or more causal models which are being compared. A regression is done for each variable in the model as a dependent on others which the model indicates are causes. Path analysis requires the usual assumptions of regression. Normally, the technique is sensitive to model specification because failure to include relevant causal variables sometimes affects the path coefficients, which are used to assess the relative importance of various direct and indirect causal paths to the dependent variables.

The next step in Structural Equation Modelling is model construction. There are four main procedures to fellow. These are model hypothesis, model specification, model identification and model estimation. There are various methods with regards to model construction. These include LISREL (Linear Structural Relationships), (Joreskog et al 1979), Bentler-Weeks-Model (Bentler 1980) and EQS Software. Other includes Mplus (Muthen and Muthen, 2000) and a much recent one called AMOS (Arbuckle, 1997) which is graphical and intuitive. This current study adopts AMOS because of its current nature.

Stating hypotheses which is part of model construction should be done with a lot of caution. A wrong hypothesis may lead to spurious regression and wrong interpretation. The hypotheses stated for this study are as follows

i. $\quad \mathrm{H}_{1}$ : Students' fear of crime does not positively and significantly influence students perceived security procedural fairness

ii. $\quad \mathrm{H}_{2}$ : Students' fear of crime does not positively and significantly influence students perceived security personnel's effectiveness

iii. $\quad \mathrm{H}_{3}$ : Students perceived security corruption does not positively and significantly affect students perceived security procedural fairness

iv. $\quad \mathrm{H}_{4}$ : Students' fear of crime does not positively and significantly influence students perceived trust in security personnel

v. $\mathrm{H}_{5}$ : Students perceived security corruption does not positively and significantly affect students perceived security effectiveness

vi. $\quad \mathrm{H}_{6}$ : Students perceived security corruption does not positively and significantly affect students perceived trust in security personnel

Diagrammatically, by using AMOS method, the hypothesis could be shown in the figure below 


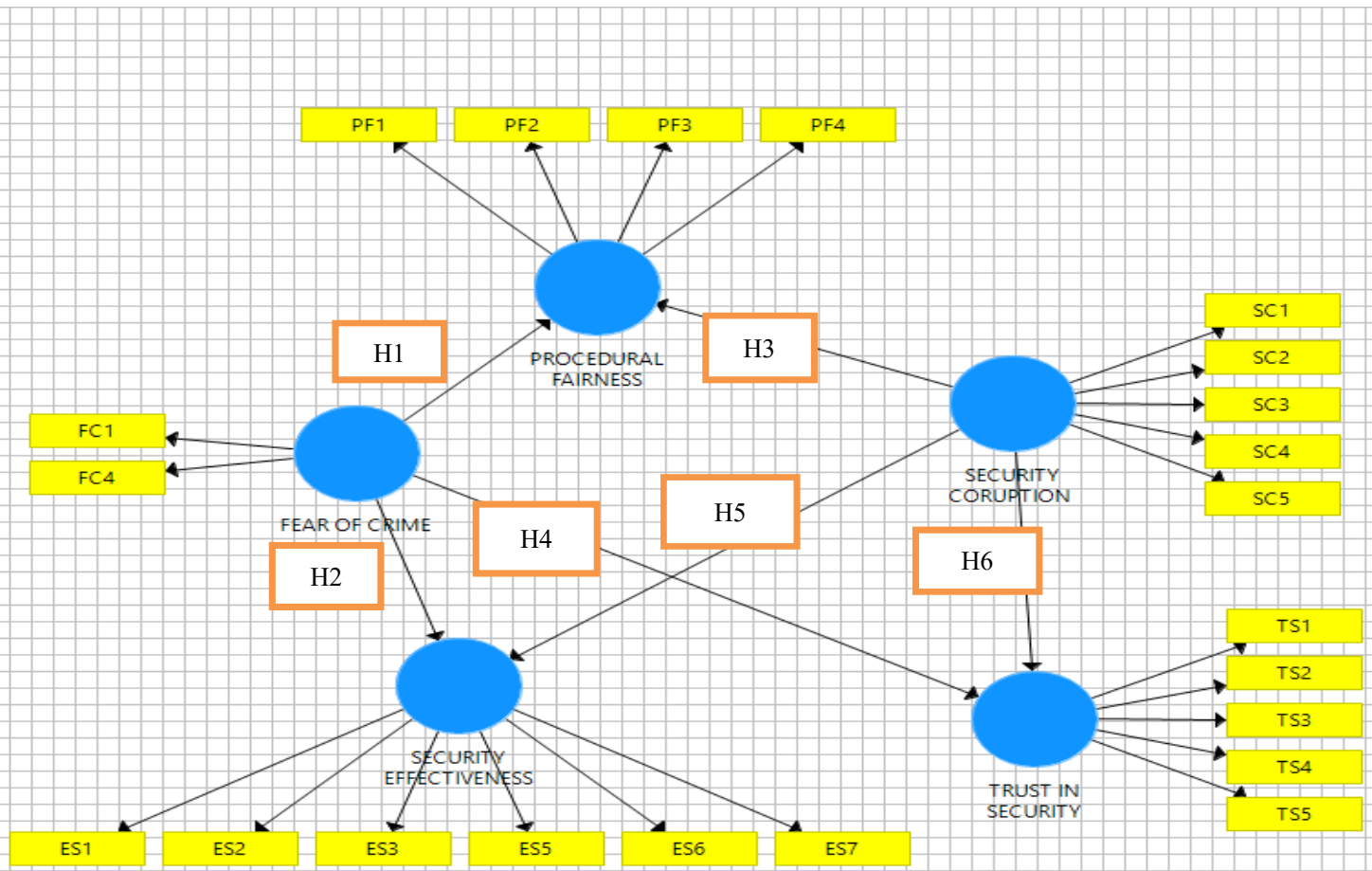

Figure 2: Final Conceptual Model on Campus Security

Figure 2 above attempts to incorporate hypothetical statements that show the possible relationship between and among variables. The Stated hypothesis $\mathrm{H}_{1}, \mathrm{H}_{2}, \mathrm{H}_{3}, \mathrm{H}_{4}, \mathrm{H}_{5}$, and $\mathrm{H}_{6}$ found in section 1 of the study are shown diagrammatically. These hypothetical statements show the direction of relationship between the variables.

After stating the correct hypothesis, the model specification procedure is next. Again once can specify a model with different methods; example Bentler-Weeks or LISREL. Specification of a model requires making formal and explicit statement about the number of common factors, the number of observed variables, the variances and covariances among the common factors, the relationships among observed variables and latent factors, the relationships among residual variables and the variances and covariances among the residual variables (Joreskog et al., 1989). Having taken into consideration, the above elements, the model specification of the equation in matrix form is as follows

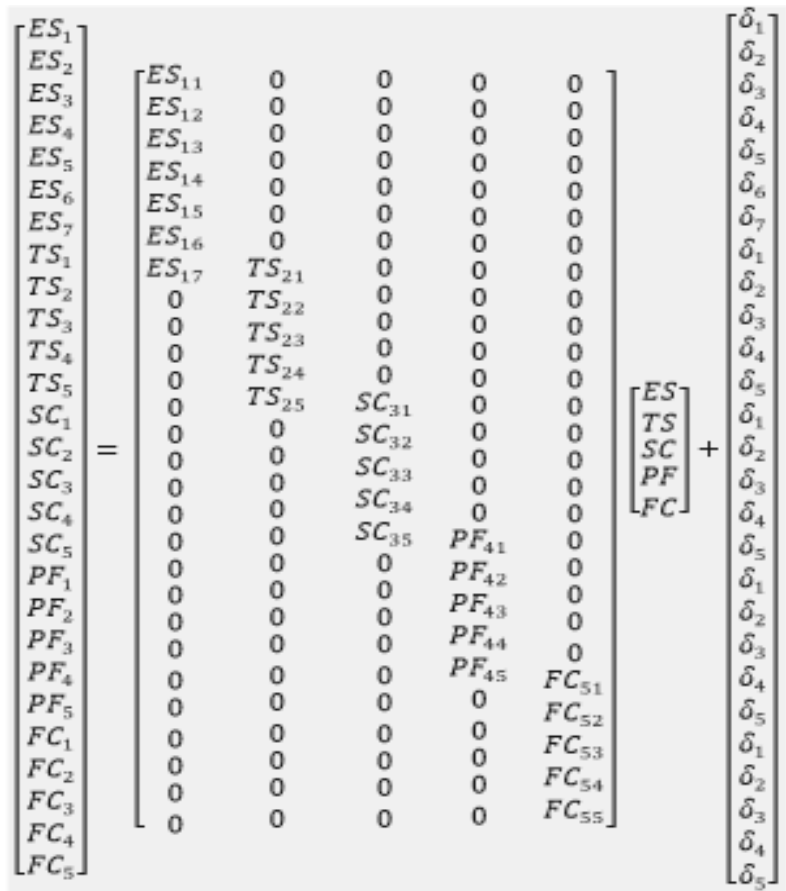

Where $E S_{1} \ldots E S_{7}, T S_{1} \ldots T S_{2}, S C_{1} \ldots S C_{5}, P F_{1} \ldots P F_{5}, F C_{1} \ldots F C_{5}$, is the linear combination of the latent variable, the coefficient of $\mathrm{ES}_{1}$ is $\mathrm{ES}_{11}$ indicating that a unit change in a latent variable results in an average change in of $\mathrm{ES}_{11}$ unit, $\delta_{1 i}$ is the residual factor of each observed value. 


\section{Results and Discussion}

Before the results are discussed, various diagnostic tests were carried out to establish the correctness of the specified model. These tests include analysis of construct reliability and validity, test of significance of average variance extracted, test of discriminant Validity and test of multicollinearity using variance inflation factor. The results of these tests are displaced below

Table 1 Analysis of Construct Reliability and Validity

\begin{tabular}{|l|c|c|c|c|}
\hline \multicolumn{5}{|c|}{ Construct Reliability and Validity } \\
\hline Fear of crime & $\begin{array}{c}\text { Cronbach's } \\
\text { Alpha }\end{array}$ & rho_A & Composite Reliability & $\begin{array}{c}\text { Average Variance } \\
\text { Extracted (AVE) }\end{array}$ \\
\hline Procedural fairness & 0.401 & 0.603 & 0.740 & 0.602 \\
\hline Security corruption & 0.775 & 0.820 & 0.856 & 0.605 \\
\hline Security effectiveness & 0.888 & 0.980 & 0.897 & 0.638 \\
\hline Trust in security & 0.896 & 0.901 & 0.920 & 0.659 \\
\hline
\end{tabular}

Table 2: Test of significance of Average Variance Extracted

\begin{tabular}{|c|c|c|c|c|c|c|}
\hline & $\begin{array}{l}\text { Original } \\
\text { Sample }(\mathrm{O})\end{array}$ & $\begin{array}{l}\text { Sample Mean } \\
\text { (M) }\end{array}$ & $\begin{array}{l}\text { Standard } \\
\text { (STDEV) }\end{array}$ & Deviation & $\begin{array}{l}\text { T } \quad \text { Statistics } \\
(|\mathrm{O} / \mathrm{STDEV}|)\end{array}$ & $\begin{array}{l}\mathrm{P} \\
\text { Values }\end{array}$ \\
\hline Fear of crime & 0.602 & 0.602 & 0.029 & & 21.064 & 0.000 \\
\hline $\begin{array}{l}\text { Procedural } \\
\text { fairness }\end{array}$ & 0.605 & 0.621 & 0.041 & & 14.808 & 0.000 \\
\hline $\begin{array}{l}\text { Security } \\
\text { corruption }\end{array}$ & 0.638 & 0.571 & 0.151 & & 4.235 & 0.000 \\
\hline $\begin{array}{l}\text { Security } \\
\text { effectiveness }\end{array}$ & 0.659 & 0.659 & 0.023 & & 28.264 & 0.000 \\
\hline Trust in security & 0.643 & 0.642 & 0.025 & & 25.540 & 0.000 \\
\hline
\end{tabular}

Table 3: Test of Discriminant Validity

Fornell-larcker criterion discriminant validity

\begin{tabular}{|lccccc|}
\hline & $\begin{array}{c}\text { Fear of } \\
\text { crime } \\
\text { Fear of crime }\end{array}$ & $\begin{array}{l}\text { Procedural } \\
\text { fairness }\end{array}$ & $\begin{array}{c}\text { Security } \\
\text { corruption }\end{array}$ & $\begin{array}{c}\text { Security } \\
\text { effectiveness }\end{array}$ & $\begin{array}{l}\text { Trust } \\
\text { security }\end{array}$ \\
$\begin{array}{l}\text { Procedural } \\
\text { fairness }\end{array}$ & 0.547 & 0.778 & & & \\
$\begin{array}{l}\text { Security } \\
\text { corruption }\end{array}$ & -0.047 & -0.139 & 0.799 & & 0.812 \\
$\begin{array}{l}\text { Security } \\
\text { effectiveness }\end{array}$ & 0.623 & 0.701 & -0.115 & 0.709 & 0.802 \\
Trust in security & 0.845 & 0.682 & -0.105 & & \\
\hline
\end{tabular}

Table 4: Test of Discriminant Validity using HTMT

\begin{tabular}{|c|c|c|c|c|c|}
\hline \multicolumn{6}{|c|}{ Heterotrait-monotrait ratio (htmt) } \\
\hline & $\begin{array}{l}\text { Fear of } \\
\text { crime }\end{array}$ & $\begin{array}{l}\text { Procedural } \\
\text { fairness }\end{array}$ & $\begin{array}{l}\text { Security } \\
\text { corruption }\end{array}$ & $\begin{array}{l}\text { Security } \\
\text { effectiveness }\end{array}$ & $\begin{array}{l}\text { Trust in } \\
\text { security }\end{array}$ \\
\hline Fear of crime & & & & & \\
\hline $\begin{array}{l}\text { Procedural } \\
\text { fairness }\end{array}$ & 0.874 & & & & \\
\hline $\begin{array}{l}\text { Security } \\
\text { corruption }\end{array}$ & 0.140 & 0.124 & & & \\
\hline $\begin{array}{l}\text { Security } \\
\text { effectiveness }\end{array}$ & 0.942 & 0.829 & 0.102 & & \\
\hline Trust in security & 1.219 & 0.839 & 0.102 & 0.799 & \\
\hline
\end{tabular}


Table 5: Significance test HTMT for Discriminant Validity Heterotrait-monotrait ratio (htmt) mean, stdev, t-values, p-values

\begin{tabular}{|c|c|c|c|c|c|}
\hline & $\begin{array}{l}\text { Original } \\
\text { sample (o) }\end{array}$ & $\begin{array}{l}\text { Sample } \\
\text { mean }(\mathrm{m})\end{array}$ & $\begin{array}{l}\text { Standard } \\
\text { deviation (stdev) }\end{array}$ & $\begin{array}{l}\text { T statistics } \\
(\mid \mathrm{o} / \text { stdev } \mid)\end{array}$ & $\begin{array}{l}\mathrm{P} \\
\text { value } \\
\mathrm{S}\end{array}$ \\
\hline $\begin{array}{l}\text { Procedural fairness }->\text { fear of } \\
\text { crime }\end{array}$ & 0.874 & 0.893 & 0.106 & 8.236 & 0.000 \\
\hline $\begin{array}{l}\text { Security corruption }->\text { fear of } \\
\text { crime }\end{array}$ & 0.140 & 0.188 & 0.049 & 2.885 & 0.004 \\
\hline $\begin{array}{l}\text { Security corruption } \\
\text { procedural fairness }\end{array}$ & 0.124 & 0.144 & 0.043 & 2.891 & 0.004 \\
\hline $\begin{array}{l}\text { Security effectiveness }->\text { fear } \\
\text { of crime }\end{array}$ & 0.942 & 0.956 & 0.101 & 9.365 & 0.000 \\
\hline $\begin{array}{l}\text { Security effectiveness } \\
\text { procedural fairness }\end{array}$ & 0.829 & 0.831 & 0.036 & 23.288 & 0.000 \\
\hline $\begin{array}{l}\text { Security effectiveness } \\
\text { security corruption }\end{array}$ & 0.102 & 0.128 & 0.035 & 2.948 & 0.003 \\
\hline $\begin{array}{l}\text { Trust in security }->\text { fear of } \\
\text { crime }\end{array}$ & 1.219 & 1.238 & 0.114 & 10.731 & 0.000 \\
\hline $\begin{array}{l}\text { Trust in security }->\text { procedural } \\
\text { fairness }\end{array}$ & 0.839 & 0.840 & 0.033 & 25.745 & 0.000 \\
\hline $\begin{array}{l}\text { Trust in security }->\text { security } \\
\text { corruption }\end{array}$ & 0.102 & 0.129 & 0.035 & 2.910 & 0.004 \\
\hline $\begin{array}{l}\text { Trust in security }->\text { security } \\
\text { effectiveness }\end{array}$ & 0.799 & 0.799 & 0.036 & 21.959 & 0.000 \\
\hline
\end{tabular}

Table 6: Test of multicollinearity using variance inflation factor

\begin{tabular}{|cc|}
\hline & Outer VIF Values \\
ES1 & 2.025 \\
ES2 & 1.922 \\
ES3 & 2.243 \\
ES5 & 2.156 \\
ES6 & 3.067 \\
ES7 & 2.586 \\
FC1 & 1.067 \\
FC4 & 1.067 \\
PF1 & 1.186 \\
PF2 & 2.185 \\
PF3 & 2.249 \\
PF4 & 1.510 \\
SC1 & 2.137 \\
SC2 & 2.598 \\
SC3 & 2.541 \\
SC4 & 2.494 \\
SC5 & 2.050 \\
TS1 & 1.676 \\
TS2 & 1.808 \\
TS3 & 2.121 \\
TS4 & 2.068 \\
TS5 & 2.043 \\
\hline
\end{tabular}

The analysis of the reflective constructs shows that most of the factor loadings exhibit values above 0.7 which indicates as strong goodness-of-fit, however, the factor loading less than 0.5 were eliminated during the final modelling. The results further indicated that the composite reliability of each construct were uniformly higher than 0.7 while the Cronbach's alpha are also above 0.7 with exception of fear of crime construct. This result further indicates that, except for the fear of crime whose Cronbach's alpha is below the stipulated threshold of above 0.7, all constructs met the stipulated threshold. In evaluating the discriminant validity using Fornell/Larcker(1981) criterion, in this criterion square root of each constructs average variance extracted (AVE) is compared with its bivariate correlations with all opposing constructs. The results clearly indicates that the square root of AVE is greater 
than the variance shared between each bi-variate correlation of two opposing construct. The result further indicates that the discriminant validity between the constructs is confirmed. The R-square value for procedural fairness, trust in security and security effectiveness are $0.312,0.718$ and 0.395 respectively. These findings indicates that students perceived security corruption and fear of crime significantly predict students perceived trust in the security, security procedural fairness, and security effectiveness.

After it was found that the various diagnostic test showed a positive results, the authors continued by testing for an initial empirical evidence for the model.

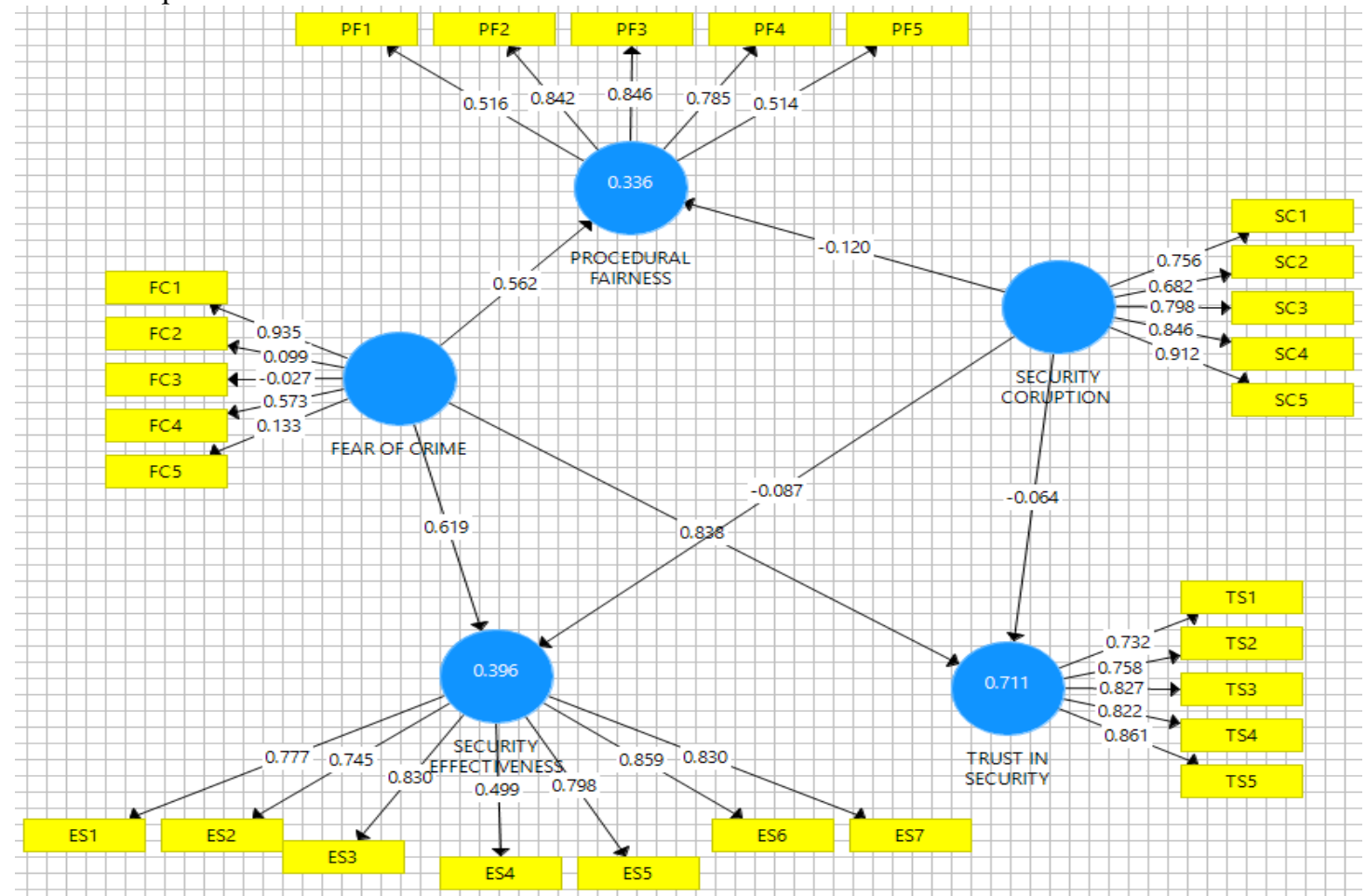

Figure 3: Initial Empirical Model of Campus Safety

From the initial results it was realized that the influence of perceived fear of crime and security corruption on students perceived security effectiveness showed a significant relations. Influence of fear of crime on security effectiveness was 0.619. This means that there is a positive relationship between inclination to walk with a friend during dark hours, avoiding poorly lit roads, locking residential hall room door and windows are night and notifying security of suspicious individuals and preventive efforts, deterrent efforts, deterrent severity, industry type, organizational size and top management support. Perceived corruption however has a negative effects on security effectives but such relation was however not strong.

The initial results showed a strong and positive relationship between perceived fears of crime on students' perceived trust in security. Similar results were found between fears of crime on procedural fairness. However, there was a negative relationship between security corruption and procedural fairness. This is to be expected as corruption would dray fairness in the handling of crime.

\subsection{Results of Path Analysis}

The results of path analysis being the main model are displayed below. 
Table 7: Test of significance of path coefficients Path coefficients mean, stdev, t-values, $\mathrm{p}$-values

\begin{tabular}{|c|c|c|c|c|c|}
\hline & $\begin{array}{l}\text { Original } \\
\text { sample (o) }\end{array}$ & $\begin{array}{l}\text { Sample } \\
\text { mean }(\mathrm{m})\end{array}$ & $\begin{array}{l}\text { Standard } \\
\text { deviation (stdev) }\end{array}$ & $\begin{array}{l}\mathrm{T} \quad \text { statistics } \\
(|\mathrm{o} / \mathrm{stde}|)\end{array}$ & $\begin{array}{l}\mathrm{P} \\
\text { values }\end{array}$ \\
\hline $\begin{array}{l}\text { Fear of crime }->\text { procedural } \\
\text { fairness }\end{array}$ & 0.542 & 0.546 & 0.042 & 12.869 & 0.000 \\
\hline $\begin{array}{l}\text { Fear of crime }->\text { security } \\
\text { effectiveness }\end{array}$ & 0.619 & 0.620 & 0.035 & 17.546 & 0.000 \\
\hline $\begin{array}{l}\text { Fear of crime } \rightarrow \text { trust in } \\
\text { security }\end{array}$ & 0.842 & 0.842 & 0.014 & 61.537 & 0.000 \\
\hline $\begin{array}{l}\text { Security corruption } \\
\text { procedural fairness }\end{array}$ & -0.114 & -0.109 & 0.059 & 1.938 & 0.053 \\
\hline $\begin{array}{l}\text { Security corruption ->security } \\
\text { effectiveness }\end{array}$ & -0.086 & -0.086 & 0.048 & 1.791 & 0.073 \\
\hline $\begin{array}{l}\text { Security corruption }->\text { trust in } \\
\text { security }\end{array}$ & -0.066 & -0.066 & 0.035 & 1.901 & 0.057 \\
\hline
\end{tabular}

Influence of perceived fear of crime and security corruption on students perceived security effectiveness.

The path coefficient from fear of crime to students perceived security effectiveness (0.619) with t-values 12.87 at $5 \%$ level of significance which indicates positive impact on perceived security effectiveness. There is direct relationship between students' fear of crime and the students perceived security effectiveness. This shows that students tend to see campus security as effective due to their fear of crime on campus. Thus student perceived security effectiveness is affected their fear of crime on campus. The more campus security effectively clamp down crime related actives on campus the more effective students perceive their operations. Moreover, the finding indicates that students perceived security effectiveness is significantly ( $p$-value $<0.05$ ) predicted by students' perceived fear of crime.

The path coefficient from security corruption to students perceived security effectiveness $(-0.086)$ with tvalue 17.55 at $5 \%$ level significance which indicated that there is negative impact perceived security effectiveness and inverse relationship between students perceived security corruption and security effectiveness. Moreover, the finding suggested that students' perception of campus security effectiveness decrease as the students perceived them to be corrupt. Furthermore the findings suggest that perceived student corruption of campus security officers does not significantly predict security effectiveness ( $p$-value $>0.05$ ).

Influence of perceived fear of crime and security corruption on students perceived trust in the security The path coefficient from fear of crime to students perceived trust in campus security (0.842) with t-value (61.54) at $5 \%$ level of significance which indicates a positive impact on students' perceived trust in campus security. There is direct relationship between students' fear of crime and the students perceived trust in campus security. This shows that students tend to exhibit trust in the security as they see campus security deal with crime on campus. This implies the student perceived fear of crime affect their trust in campus security operations.

The more campus security effectively clamp down crime related actives on campus the more students trust in the security operation on campus. Moreover, the finding indicates that students perceived trust in campus security is significantly $(\mathrm{p}$-value $<0.05)$ predicted by students' perceived fear of crime.

The path coefficient from security corruption to students perceived trust in campus security (-0.086) with tvalue 1.901 at $5 \%$ level significance indicated that there is negative impact on students perceived trust in campus security by security corruption and inverse relationship between students perceived security corruption and students perceived trust in campus security. Moreover, the finding suggested that students' perception trust in campus security decrease as the students perceived them to be corrupt, however the less corrupt students perceive campus security the higher students perceived trust in campus security. Furthermore the findings suggest that perceived student corruption of campus security officers does not significantly predict security effectiveness (pvalue $>0.05)$.

Influence of perceived fear of crime and security corruption on students perceived security procedural fairness The path coefficient from fear of crime to students perceived security effectiveness (0.619) with t-values 12.87 at $5 \%$ level of significance which indicates positive impact on perceived security effectiveness. There is direct relationship between students' fear of crime and the students perceived security effectiveness. This shows that students tend to see campus security as effective due to their fear of crime on campus. Thus student perceived security effectiveness is affected their fear of crime on campus. The more campus security effectively clamp down crime related actives on campus the more effective students perceive their operations. Moreover, the finding 
indicates that students perceived security effectiveness is significantly ( $p$-value $<0.05$ ) predicted by students' perceived fear of crime.

The path coefficient from security corruption to students perceived security effectiveness $(-0.086)$ with tvalue 17.55 at $5 \%$ level significance which indicated that there is negative impact perceived security effectiveness and inverse relationship between students perceived security corruption and security effectiveness. Moreover, the finding suggested that students' perception of campus security effectiveness decrease as the students perceived them to be corrupt. Furthermore the findings suggest that perceived student corruption of campus security officers does not significantly predict security effectiveness ( $p$-value $>0.05)$.

The above results are shown in the diagram below where path analysis is undertaken. The diagram confirms all analysis undertaken.

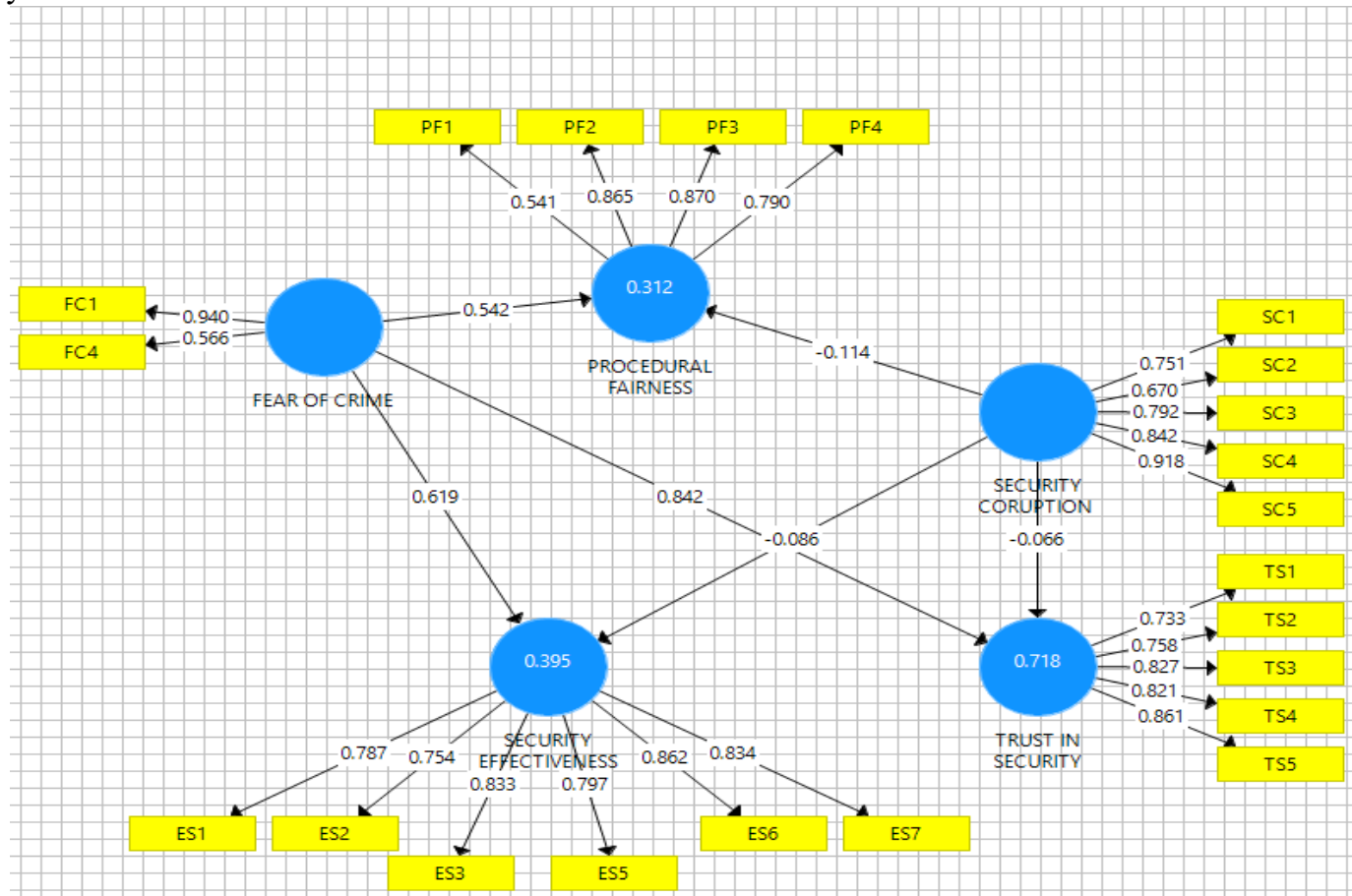

Figure 4: Final Empirical Model of Campus Security

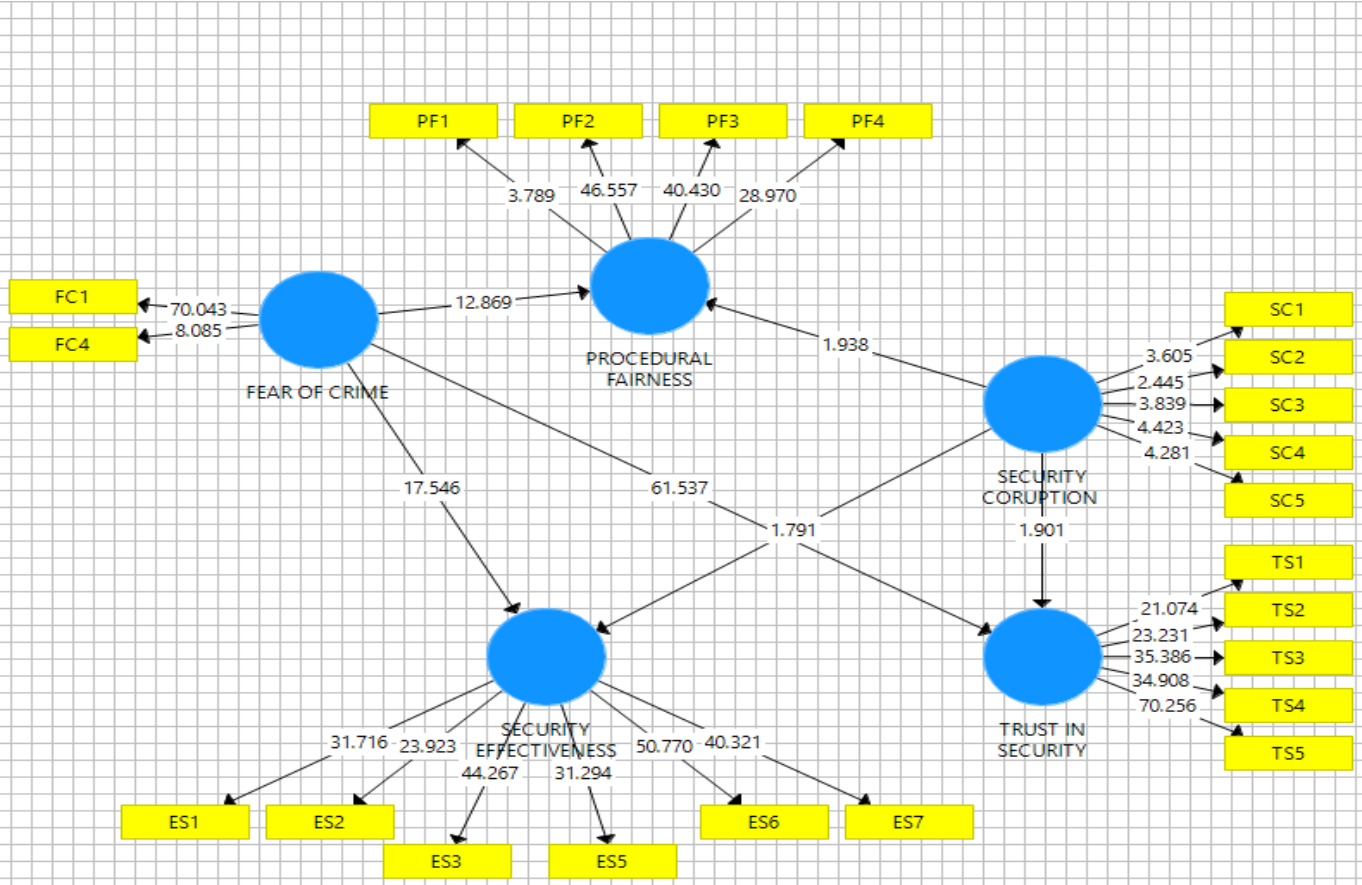

Figure 5: Boostrap Empirical Model of Campus Safety 


\subsection{Conclusions and Recommendations}

The study modelled how security corruption on campus and students fear of crime on campus influence the security personnel's effectiveness, procedural fairness and students trust in campus security. The study concluded that students fear of crime on campus positively influence their trust in campus security, security personnel's procedural fairness and security effectiveness. The paper further concluded that security corruption on campus negatively influence their procedural fairness, students trust in security and security effectiveness.

The authors recommend that training programmes should be put in place regularly to sensitise personnel's on the effect of corruption on their integrity and profession.

\section{Reference}

Amoatemaa, A. S., Kyeremeh, D. D., \& Arthur, Y. D. (2017). Students Perception of Campus Safety: A Case of Kumasi Campus of University of Education, Winneba, Ghana. Asian Research Journal of Arts \& Social Sciences, 1-9

Bollen, K. A., \& Long, J. S. (1993). Testing structural equation models (Vol. 154). Sage.

Conrath, R. C. (1976), In Loco Parentis: Recent Developments in this Legal Doctrine as Applied to the UniversityStudent Relationship in the United States of America, 1965-75.

Cutrone, J. (2010). Student Perceptions of Campus Safety Initiatives: Assessing Views of Critical Incident Prevention \&.

De Cremer, D., Brockner, J., Fishman, A., Van Dijke, M., Van Olffen, W., \& Mayer, D. M. (2010), When do procedural fairness and outcome fairness interact to influence employees' work attitudes and behaviors? The moderating effect of uncertainty, Journal of Applied Psychology, 95(2), 291

Gregory, J. R. (2015). Problematizing Solutions: A Case Study of Claims about Campus Safety in an Era of 'School Violence'(Doctoral dissertation).

Gomme, I., \& Micucci, A. (1997). Loose connections: Crime and policing on the university campus. Canadian journal of higher education, 27(1), 41-68.

Howe, M. (2015). "We're More Than Just The Guys With The Keys": The Professional Identity of Campus Security at an Atlantic Canadian University (Doctoral dissertation)

Hox, J. J., \& Bechger, T. M. (1998), An introduction to structural equation modeling.

Institute of Legislative Action (2016), Setting the Records Straight: Georgia's Campus Carry Bill, https://www.nraila.org/articles/20160427/setting-the-record-straight-georgias-campus-carry-bill

Kankanhalli, A., Teo, H. H., Tan, B. C., \& Wei, K. K. (2003). An integrative study of information systems security effectiveness. International journal of information management, 23(2), 139-154

Kren, C. (2017). Student Perceptions of Campus Safety and Physical/Sexual Assault (Doctoral dissertation, The Ohio State University)

Layden, D. R. (2010). Campus violence: lessons from the cases. National Social Science Journal, 33(2), 106-115

Langford, L. (2004). Preventing Violence and Promoting Safety in Higher Education Settings: Overview of a Comprehensive Approach. Higher Education Centre for Alcohol and Other Drug Abuse and Violence Prevention

Muscat, K. (2011). Rowan University students' perceptions of campus safety

Miller, K. N. (2011). The relation of school and campus violence to students' perceptions of safety and precautionary behaviors (Doctoral dissertation)

Oluwajana, T. (2017). Students Perception of Safety in Campus VIS A VIS Crime and Violence-A Case Study of ECU

Pendlay, E. L. (2006), Procedure for Pupils: What Constitutes Due Process in a University Disciplinary Hearing. NDL Rev., 82, 967.

Pezza, P. E., \& Bellotti, A. (1995). College campus violence: Origins, impacts, and responses. Educational Psychology Review, 7(1), 105-123

Simmons, L. (2007). Security Culture on Campus: Considerations for Urban Universities. Metropolitan Universities, 18(2), 57-65.

Scalora, M., Simons, A., \& VanSlyke, S. (2010). Campus safety: Assessing and managing threats. FBI L. Enforcement Bull., 79, 1

Sulkowski, M. L. (2011). An investigation of students' willingness to report threats of violence in campus communities. Psychology of Violence, 1 (1), 53-65.

Seo, D. C., Torabi, M. R., Sa, J., \& Blair, E. H. (2012). Campus violence preparedness of US college campuses. Security journal, 25(3), 199-211

The Conversation (2016), Students more at risk of crime than public - universities must rethink how to keep them safe, http://theconversation.com/students-more-at-risk-of-crime-than-public-universities-must-rethinkhow-to-keep-them-safe-52620

Volkwein, J. F., Szelest, B. P., \& Lizotte, A. J. (1995). The relationship of campus crime to campus and student 
characteristics. Research in Higher Education, 36(6), 647-670

Wilcox, P., Jordan, C. E., \& Pritchard, A. J. (2007). A multidimensional examination of campus safety: Victimization, perceptions of danger, worry about crime, and precautionary behavior among college women in the post-Clery era. Crime \& Delinquency, 53(2), 219-254.

Wolf, R., Mesloh, C., \& Henych, M. (2007). Fighting campus crime: Perceptions of police canines at a metropolitan university. Critical Issues in Justice \& Politics, 3(1), 1-18 